\title{
Laboratory Options for Risk Assessment of Pregnancy Pathologies
}

\author{
A. KESTLEROVÁ ${ }^{1}$, L. KROFTA ${ }^{2}$, A. ŽUFIĆ ${ }^{3}$, K. HAMPLOVÁ BĚHÁVKOVÁ ${ }^{2}$ \\ J. RAČKO ${ }^{3}$, J. BENES̆ ${ }^{1,4}$, J. FEYEREISL ${ }^{2}$
}

${ }^{1}$ Institute of Biophysics and Informatics, First Faculty of Medicine, Charles University, Prague, Czech Republic, ${ }^{2}$ Institute for the Care of Mother and Child, Prague, Czech Republic, ${ }^{3}$ Faculty of Science, Charles University, Prague, Czech Republic, ${ }^{4}$ Institute of Biophysics, Second Faculty of Medicine, Charles University, Prague, Czech Republic

Received October 20, 2019

Accepted November 7, 2019

\begin{abstract}
Summary
The most effective method of screening for chromosomal abnormalities and evaluating the risk of pregnancy pathologies in the first trimester is combined screening. The algorithm of screening is based on the combination of maternal age, measuring of the nuchal translucency and the fetal heart rate and analysis of the placental products of free B-hCG and PAPP-A. For the screening of preeclampsia, placental growth factor (PIGF) is added. To distinguish between preeclampsia and other pathologies caused by placental dysfunction it is recommended to also extend the screening with selected immunological markers. We concluded that elevated biochemical and immunological markers can help to predict the threat of preeclampsia in the third trimester. Some markers can probably predict the development of particularly severe pathological conditions.
\end{abstract}

\section{Key words}

Pregnancy • Pathologies • Laboratory markers • Preeclampsia

\section{Corresponding author}

A. Kestlerova, Institute of Biophysics and Informatics, Salmovská 1, First Faculty of Medicine, Charles University, 12000 Prague, Czech Republic. E-mail: 1andrea1@centrum.cz

\section{Clarification of normal outcome of the pregnancy and pregnancy pathologies}

The definitions below are based on 2002 guidelines from the American College of Obstetricians and Gynecologists (ACOG), updated and verified by the international symposium on hypertension in pregnancy (ACOG 2002, Levine 1997, Sibai 1998, Wagner 2004, Orr 2015).

\section{Normal outcome}

Normal outcome of the pregnancy involves delivery at the term ( $\geq 37$ weeks) of a live baby with birth weight $>5 \%$-lower percentile and with none of the symptoms associated with pregnancy pathologies.

\section{Chromosomal aneuploidies}

Aneuploidy causes several human conditions and diseases including Down syndrome, mosaic variegated aneuploidy (MVA), and is associated with cancer. These disorders illustrate how aneuploidy can arise under different circumstances in an organism. Constitutional aneuploidy, prevalent in conditions such as Down syndrome, typically arises through fertilization of an aneuploid gamete generated through defective chromosome segregation during meiosis. Somatic aneuploidy is acquired through defective chromosome segregation in mitosis and is characteristic of individuals with MVA and is found in over $90 \%$ of solid tumors.

Pre-eclampsia (PE)

PE have been considered to be a new onset hypertension after the $20^{\text {th }}$ gestational week combined with proteinuria $\geq 300 \mathrm{mg}$ per day. Heterogenity of the disorder is more and more appreciated and therefore new diagnostic criteria have recently been introduced. 
Proteinuria has been questioned as a sine qua non. According to the two new diagnostic criteria by The American College of Obstetricians and Gynecologists (ACOG) in 2013 and International Society for the Study of Hypertension in Pregnancy (ISSHP) in 2014, new onset hypertension in the absence of proteinuria but combined with hematological complications, renal insufficiency, impaired liver function, neurological symptoms, or uteroplacental dysfunction also fulfill diagnostic criteria for PE. This is to provide a broader definition of PE for clinical practice leaving proteinuria to ensure specificity of the diagnosis in scientific purposes. Affecting approximately 3-5\% of pregnancies and causing as much as $10 \%$ of pregnancy related complications, better diagnostic criteria are needed to improve the recognition of PE and its diverse subtypes mild and severe.

\section{Eclampsia}

Eclampsia is a dangerous form of PE where blurred vision, apathy, nausea and dizziness turn into convulsions, indicating the severe disorder has affected the brain and the woman is experiencing a threat to her life.

\section{HELLP Syndrome}

HELLP Syndrome is a rapidly developing life threatening condition comprising hemolysis, elevated liver enzymes and low platelets $(<100000$ cells per $\mu 1)$.

HELLP Syndrome occurs in tandem with PE, but because HELLP Syndrome's symptoms may appear before those characteristic of PE, they may be easily misdiagnosed.

Partial HELLP is the term applied when a woman meets one or two of the criteria for HELLP but not all three.

Pregnancy induced hypertension (PIH) or gestational hypertension (GH)

PIH is definited with blood pressure of $>140 / 90 \mathrm{~mm} \mathrm{Hg}$ measured normally 4-6 hours apart in previously normotensive women.

\section{Intrauterine growth restriction (IUGR)}

IUGR is the failure of the fetus to realize its growth potential as a result of genetic environmental factors. Approximately $30 \%$ of IUGR cases are associated with chromosomal aberrations. A number of PE cases are associated with the delivery of IUGR babies.

\section{Small for gestational age ( $S G A)$}

Small for gestational age babies are those with birth weight below the $10^{\text {th }}$ percentile for their gestational age.

\section{Preterm delivery (PTD)}

Preterm delivery applies to pregnancy outcome when delivery is before 37 complete weeks of gestation.

\section{Selection markers}

\section{Alpha-fetoprotein (AFP)}

In the mid-1970s, raised levels of maternal serum alpha fetoprotein (AFP) was shown to be a useful second-trimester screening test for open spina bifida and anencephaly (Brock and Sutcliffe 1972). In the early 1980s Merkatz and colleagues investigated the possibility that low maternal serum alpha-fetoprotein (AFP), obtained from maternal blood in the second trimester of pregnancy could be associated with chromosomal abnormalities in the fetus. Their retrospective case-control study showed a statistically significant relationship between fetal trisomy, such as Down's syndrome, and lowered maternal serum AFP (Merkatz et al. 1984). These results were explored by Cuckle and colleagues in a larger retrospective trial using data collected as part of a neural tube defect (NTD) screening project (Cuckle et al. 1984). When used unconjugated oestriol (uE3) in combination with AFP and maternal age, it appeared to identify more pregnancies affected by Down's syndrome than AFP and age alone (Canick et al. 1988). Further work suggested that all three serum markers (AFP, hCG and $\mathrm{uE} 3$ ) showed even higher detection rates when combined with maternal age (Wald et al. 1988) and appeared to be a cost-effective screening strategy (Wald et al. 1992).

AFP had been tested for a long time only in the second trimester of pregnancy, then researchers began performing AFP tests in the first trimester of pregnancy. The study containing cases of exomphalos, anencephaly and two cases of open spina bifida also confirmed that first-trimester maternal serum AFP was increased in cases with anencephaly and exomphalos but not in the two cases with open spina bifida (Sebire et al. 1997). A recent first trimester study of cases with anencephaly confirmed the elevation of maternal serum AFP, however, this same study also found elevation of maternal serum AFP in cases with open spina bifida (Bredaki et al. 2012). A further study of 44 cases of open spina bifida found a small but significant increase in maternal serum AFP in 
addition to a small but significant decrease in free $\beta$-hCG (Bernard et al. 2013). On the basis of the study of Bernard and the results of study of Spencer (Spencer et al. 2014) in conjunction with studies published in 1993 (Aitken et al. 1993), one cannot confirm the value of first-trimester maternal serum AFP as a possible screening marker for open spina bifida in the first trimester. Spencer thinks, that one possible explanation for the differences between the few studies may be how cases identified by second trimester ultrasound are accurately classified as open spina bifida as opposed to closed lesions. Because most cases of closed spina bifida are not identified until term unless a detailed fetal examination is undertaken on the fetus, a clear diagnosis may not be possible. This in itself could lead to some heterogeneity amongst the cases. In the more recent publications (Bredaki et al. 2012, Bernard et al. 2013) there was no indication that diagnosis was confirmed by fetal exam, only that diagnosis occurred as a result of second trimester ultrasonography (Spencer et al. 2014).

\section{Fee beta $H C G$ and $P A P P a$}

Human chorionic gonadotropin (hCG) free $\beta$-subunit measurement, together with pregnancy associated protein A (PAPP-A) is used as a screening test for Down syndrome during the first trimester of pregnancy. Combination of both parameters has higher distinctive value; however, it also brings some problems. Difficulties arise mainly from low stability of free $\beta$-hCG subunit. In collected blood, free $\beta$-subunit does not dissociate but it is subjected to nicking and other forms of degradation even in properly separated serum (Springer et al. 2008). Nicked free $\beta$-hCG lacks peptide linkages between either $\beta$-subunit residues 44 and 45 or $\beta$-subunit residues 47 and 48 . The percentage of nicked free $\beta$-hCG increases after the second month of pregnancy (Cole and Kardana 1993, Cole and Kardana 1997).

Pregnancy associated plasma protein-A (PAPP-A) is a high-molecular-weight zinc-binding metalloproteinase belonging to metzincin superfamily of metalloproteinases and was originally identified in the plasma of pregnant women (Lin et al. 1974, Zakiyanov et al. 2013).

PAPP-A belongs to a group of biomarkers that predict later preeclampsia development, primarily early onset preeclampsia; however, it should be combined with a Doppler ultrasonography of the uterine artery (pulsatile index) and other biochemical and maternal factors to achieve a higher detection rate with an acceptable false positivity rate (Kalousová et al. 2014).

\section{Placental growth factor (PlGF)}

Placental growth factor (PlGF), which is a member of the vascular endothelial growth factor (VEGF), stimulates angiogenesis and growth of collateral vessels in ischemic tissues via VEGF receptor-1 (Flt1) (Autiero et al. 2003, Luttun et al. 2002). PlGF is upregulated in atheromatic lesions, and antiFlt1 suppresses atherosclerotic process and plaque vulnerability (Luttun et al. 2002).

First trimester combined screening can be concentrated on risk detection of preeclampsia. The best results are reached with combination of mean arterial pressure, uterine artery pulsatility index and maternal serum level of PLGF. In pregnancies that develop PE, compared to those without $\mathrm{PE}, \mathrm{MoM}$ values of serum PAPP-A and PIGF are decreased, and the deviation from normal was greater for early than late PE (Tan et al. 2018). Combined screening by maternal factors, mean arterial pressure, uterine artery pulsatility index and PIGF predicted $90 \%$ of early PE, $75 \%$ of preterm PE and $41 \%$ of term PE (Tan 2018).

\section{Heat shock proteins (Hsps)}

Heat shock proteins (Hsps) are ubiquitously distributed phylogenetically conserved molecules present in the cells of all living organisms. Under physiological conditions, the stress proteins are expressed in low concentrations as the constitutive proteins, regulating cellular homeostasis and maintaining the integrity and function of other cellular proteins (Nover 1984, Morimotto et al. 1990).

Human Hsps are categorized under distinct families based on their functions in the cells, their homologies in the primary structures and their approximate molecular weight, measured in $\mathrm{kDa}$. These families are as follows: a family of small Hsps, Hsp40, Hsp60, Hsp70, Hsp90 and Hsp110 (Kampinga et al. 2009).

Maternal circulation can reflect both maternal and placental pathologic conditions through the mediation of diverse $H s p$ gene expression profiles. Since $H s p 60$ and $H s p B P 1$ mRNA are not detectable in maternal plasma samples and $H_{s p} 27$ and $H s p 90$ mRNA show comparable levels regardless of the course of gestation, Hsp70 represents the sole plasmatic marker. (Hromadníková et al. 2013). Elevated circulating Hsp70 concentrations reflecting systemic inflammation, oxidative stress and hepatocellular injury were found to 
be associated with an increased risk of several pregnancyrelated complications including transient hypertension of pregnancy, PE, hemolysis, elevated liver enzymes, low platelet syndrome and pre-term delivery (Jirecek et al. 2002, Molvarec et al. 2006, Molvarec et al. 2007, Molvarec et al. 2009, Paracoli et al. 2013, Madách et al. 2008, Hromadníková et al. 2013).

\section{Fetal DNA}

Circulating nucleic acids such as DNA, mRNA and microRNAs present in maternal plasma or serum samples are increasingly being used as biomarkers for monitoring of pregnancy-related complications. Extracellular nucleic acids present in maternal circulation are predominantly haematopoietic in origin (Zheng et al. 2012).

\section{Extracellular vesicles (EVS)}

In biological systems, extracellular vesicles (EVs) represent a heterogeneous population of microvesicles (MVs) with a diameter below $1000 \mathrm{~nm}$ and exosomes with a diameter mostly below $100 \mathrm{~nm}$ (in some reports up to $250 \mathrm{~nm}$ ). (Sitar et al. 2015, Lo Cicero et al. 2015, Varga et al. 2014)

Syncytial surface of the human placenta is known to shed EVs, commonly called syncytiotrophoblast microparticles (STBMs) directly to maternal blood, as a result of blebbing and programmed cell death (Roos et al. 2010, Huppertz et al. 1998, Knight et al. 1998).

STBEVs are recognised as a form of intercellular communication important for interactions between the fetus and the mother, allowing a continual adaptation of the maternal immune system throughout normal pregnancy (Messerli et al. 2010, Mincheva Nilsson et al. 2010).

Significantly elevated amounts of STBEVs have been found in the circulation of women with preeclampsia (Redman et al. 2008, Redman et al. 2005), indicating a possible causative role in a number of pathophysiological states such as systemic inflammation, endothelial damage and organ failure (Redman et al. 2012). It is still under discussion if elevated STBEV concentrations in preeclampsia are cause or consequence of this disease. STBEVs may be involved in the development of the associated hypertension (Tesse et al. 2007).

A few studies have analyzed quantities of EVs from different cell types in severe preeclampsia and have found increased amounts of EVs derived from T cells, monocytes, and granulocytes (VanWijk et al. 2002, Lok et al. 2009). Women with preeclampsia have an increased number of monocyte-, lymphocyte- and platelet- derived EVs compared with healthy pregnant women (Meziani et al. 2006). Furthermore, elevated levels of endothelial cell - derived EVs have been described in preeclampsia (Gonzalez-Quintero et al. 2004). STBEVs can alter the fibrinolytic and angiogenic balance at the maternal - fetal interface, which may be involved in the pathophysiology of preeclampsia (Guller et al. 2011). The pathomechanisms leading to preeclampsia are still not completely understood, but it may be expected that EVs are involved (Foster et al. 2016).

\section{Anti-phospholipid antibodies (APA)}

Long-lasting primary infertility or repeated pregnancy losses after spontaneous and/or artificial fertilization should be examined along with antiphospholipid abnormalities. Present levels of APA potentially improve the chance of female conception through appropriately directed treatment. Today, we have a panel of eight different phospholipids for the diagnosis of antiphospholipid syndrome. Concerning pregnancy loss, there is general agreement that $\operatorname{IgG}$ antibodies against CL, against ph-serine, ph-ethanolamine, beta-2-GPI, ph-inositol at moderate or high titer and/or LA, identify the patients with a greater risk of future obstetric complications than low-titer IgG or IgM of the same phospholipid factors. (Ulcova-Gallova et al. 2014)

Prevalence of anti-phospholipid antibodies in preeclampsia patients is twice that in healthy pregnant women. Multipositive aPL test, IgM-anti-cardiolipin and IgM-anti-ß2)glycoprotein-I isotypes showed an association with severe and early-onset preeclampsia (Ferrer-Oliveras et al. 2012). Other authors indicate that the risk of preeclampsia is markedly increased in women with anti-phospholipid syndrome (relative risk 9.72) (Duckitt and Harrington 2005), but there are no data concerning other pregnancy pathologies.

Anti-cardiolipin autoantibodies form one part of a complex phospholipid antibodies and may therefore be one of the possible indicators of pregnancy complications such as gestational hypertension or preeclampsia. The familiar relationship between elevated levels of antiphospholipid antibodies and type I diabetes (Wangel et al. 1992) might play an important role e.g. the development of gestational diabetes mellitus.

In our previous study we have shown that the 
immunological factors, i.e., increased predisposition to the autoimmune reaction, and elevated sensitivity of cellmediated immunity to the antigens of trophoblast origin, could represent a signal leading to the onset of preeclampsia (Kestlerova et al. 2012). There was a dilemma whether the elevation of anti-cardiolipin autoantibodies (ACLA) is a cause of PE or a consequence of the general inflammation accompanying PE. We proposed that the presence of anti-phospholipid autoantibodies in pregnant women was rather the cause, representing a significant risk factor for a development of PE. In order to verify this opinion, we decided to analyze the presence of ACLA as early as in the first trimester in women suffering from preeclampsia in the third trimester of gravidity. We also tried to prove whether the presence of ACLA is an exclusive marker for future preeclampsia or if it could signal other common pregnancy pathologies.

\section{Natural killers (NK), Interleukins (IL)}

Natural killer (NK) T or NKT cells are recently discovered cells. They are a small subset of TcR+ $\mathrm{T}$ lymphocytes which also express natural killer cell surface receptors (see under NK). They have a very restricted TcR repertoire. They can secrete several cytokines, especially IL-4 and IFN- $\gamma$, shortly after stimulation and kill target cells, mostly via cell/target interaction of Fas molecule with Fas L (Fas ligand). The cytokines they secrete endow them with potential immunoregulatory functions, which are exerted through their ability to induce apoptosis and to modulate the development of Th1 or Th2 cells. Finally, there exist $\mathrm{T}$ cells capable of down-regulating or 'suppressing' $\mathrm{T}$ cell effector functions. $\mathrm{T}$ regulatory cells (Tregs) have recently been described (Shao et al. 2005, Chaouat et al. 2007) and might be involved in the success of tolerance to the fetus (see below). In the same vein, transforming growth factor $\beta$ (TGF $\beta$ ) secreting Th cells (named Th0) have been described, and identified at the materno-fetal interface. Since TGF $\beta$ is both a growth factor for the embryonic derived fibroblast component of the placenta and a very potent immune suppressor, these cells have equally been implicated in the non-rejection of the fetus. (Chaouat et al. 2007)

Placental dysfunction increases syncytiotrophoblast microvesicle production leading to exaggerated systemic inflammation (Redman and Sargent 2005). In fact, treatment of peripheral blood mononuclear cells by first trimester microvesicles has been shown to increase IL1 $\beta$ secretion (Holder et al. 2012). Thus, increased systemic IL1 $\beta$ in the first trimester may indicate an immunological preeclampsia subtype perhaps mediated by abnormal placentation and increased placental microvesicles. Maternal character-ristics may impact systemic immune markers (Curry et al. 2008). Thus, second trimester controls may have been more likely to have elevated immune markers via unmeasured maternal factors biasing results towards the null. Lastly, it is also possible that a decrease in IL1 $\beta$ in the second trimester is capturing a different preeclampsia subtype (Leavey et al. 2016). Exploratory analyses of Brandies team did show that in the second trimester IL1 $\beta$ was significantly decreased in preeclampsia without SGA but displayed trends towards increased levels in preeclampsia with SGA (Brandie et al. 2016).

Initial analyses of human epithelial and Jurkat $\mathrm{T}$ cell cultures revealed a high concentration of IL-36Ra in supernatants and, to a lesser extent, in the cytoplasm, indicating the secretion of this cytokine (Towne et al. 2011). While cleavage of IL- $1 \beta$ and IL-1 18 by caspase- 1 promotes their activation and secretion (Barton et al. 2000, Debets 2001), the 17-20 kDa protein encoded for IL-36Ra lacks N-glycosylation at Asn91, a caspase cutting site and conventional leading peptide sequence (Mulero et al. 1999).

IL-18 has been described as a paracrine regulator of endometrial function. Its elevated levels have been associated with implantation failure (Ledee-Bataille et al. 2003, Ledee-Bataille et al. 2004). Human decidual and glandular cells express IL-18 whereas trophoblast cells express IL-18R, indicating its role in maternofetal communication. Moreover, IL-18 stimulates the cytotoxic capacity of uterine and peripheral blood NK cells (LedeeBataille et al. 2004, Tokmadzic et al. 2002). During normal human pregnancy, IL-18 expression is relatively high in the first and second trimester. At the labor stage, its levels are even more elevated. Furthermore, during several pregnancy disorders IL-18 concentrations are exacerbated, suggesting the participation of this cytokine in pathogenic processes (Ida et al. 2000).

IL-37 is the antagonist member of the IL-18 subfamily. An active form of $22 \mathrm{kDa}$ is generated by cleavage through caspase-1 and binds to IL-18R $\alpha$, leading to inhibition of this receptor (Kumar et al. 2002). The participation of IL-37 in pregnancy related processes remains unknown.

Expression of IL-36 cytokines has also been described in human uteri (Busfield et al. 2000, MurrietaCoxca et al. 2019). All IL-36 agonists are also expressed 
in the human placenta (Smith et al. 2000, Murrieta-Coxca et al. 2019).

A recent study reported the expression of IL-36 $(\alpha, \beta, \gamma)$ and IL-36Ra in the placenta of women with normal pregnancy and preeclampsia. Although the concentrations of IL-36 $(\alpha, \beta, \gamma)$ in serum do not change, IL-36Ra is expressed at lower levels in patients with preeclampsia who underwent emergency cesarean at 27-39 weeks of gestation compared with patients with normal pregnancy under elective cesarean at term (>38 weeks). Histologically, IL-36Ra is located around fetal blood vessels of the placental villi. Serum IL-36Ra is significantly higher in later stages of normal pregnancy compared to non-pregnant women. IL-38 seems to be also decreased in pre-eclamptic placentas (Southcombe et al. 2015). IL-36Ra and IL-38 are also relevant players in this scenario; reduction of their levels is associated with the development of inflammatory processes and contributes to dysregulated pro-inflammatory IL-36 ( $\alpha, \beta$, $\gamma$ ) activity (Marrakchi et al. 2011, Onoufriadis et al. 2011, Lea et al. 2011, Kim et al. 2008, Murrieta-Coxca et al. 2019).

IL-6 and TNF $\beta$ were associated with term preeclampsia (Tayolor 2016). The conflicting results may be due to differences in the study populations and IL6 was associated with preeclampsia but most ofen only in white women.

IL-1 $\beta$ was significantly associated with preterm preeclampsia in the first trimester and the elevation IL-1 $\beta$ in early pregnancy may indicate a subtype of preeclampsia. However, these associations were not observed in the second trimester. Longitudinal changes in IL1 $\beta$ in relation to preeclampsia subtypes may be warranted. Overall, no single immune biomarker is likely a strong predictor for preeclampsia or preeclampsia subtypes, particularly in the second trimester. Investigations which combine several immune markers, biomarkers from pathways which may induce inflammation and clinical data may be useful to define an immunological subtype of preeclampsia (Brandie 2016).

\section{C3, C4 complements}

The role of the complement system is fundamental in protecting the fetal-maternal interface against invading pathogens and in promoting the removal of immune complexes and apoptotic cells. In addition, the presence of complement inhibitors is crucial in protecting the fetus from attack by the maternal immune system.
However, excessive complement activation or the lack of complement inhibition can determine bad pregnancy outcomes in murine models. These observations were also confirmed in humans, increased circulating levels of complement proteins and their activation fragments being a common finding in patients with pre-eclampsia, recurrent miscarriage and intrauterine growth restriction (Girardi et al. 2011).

C3 complement component was without significant changes, but $\mathrm{C} 4$ complement component was reduced by woman with preeclampsia (Kestlerová et al. 2012). Measurement of serum C3 and C4 can help differentiate between SLE activity and pre-eclampsia, since both $\mathrm{C} 3$ and $\mathrm{C} 4$ are significantly lower in women with SLE than women with pre-eclampsia, and serum C3 and $\mathrm{C} 4$ concentrations rise during uncomplicated or preeclamptic pregnancy in women with SLE (Buyon et al. 1986).

\section{Imunoglobulins Ig}

B cells express $\operatorname{IgD}$ and $\operatorname{IgM}$ as cell surface receptors and secrete $\operatorname{IgM}, \operatorname{IgG}, \operatorname{IgE}$ and $\operatorname{IgA}$ antibodies. IgM, and IgG1, IgG2, and IgG3 in human are complement fixing antibodies and are thus (most of the time) cytotoxic. However, complement functions at the materno-fetal interface are blocked by specific regulatory molecules, MCP (membrane cofactor protein) and DAF (decay accelerating factor) in humans, which are expressed on germ cells, the fertilized egg and early embryo, and later on by trophoblasts. These antibodies can also act as immobilizing antibodies (especially IgM and $\operatorname{IgA}$ ), and indeed there are many cases of infertility linked to IgM or IgG antisperm agglutinating or cytotoxic antibodies; these are a concern in IVF (Kamada et al. 1985, Chaouat et al. 2007).

In our study of pregnancy pathologies in the third trimester were concentrations of serum immunoglobulins of the $\operatorname{IgA}, \operatorname{IgG}$ and $\operatorname{IgM}$ classes elevated in gestational hypertension or in preeclampsia, when compared with normal pregnancies. While in the IgA class the differences are not statistically significant, serum levels of $\operatorname{IgG}$ were markedly higher in the preeclampsia group and slightly higher also in women with gestational hypertension. IgM-class immunoglobulins were also elevated in the preeclampsia group (Kestlerová et al. 2012).

\section{Conflict of Interest}

There is no conflict of interest. 


\section{Acknowledgements}

I would like to thank prof. MUDr. Tomáš Zima, DrSc., MBA for his consultations and his expert advice.

\section{References}

ACOG COMMITTEE ON PRACTICE BULLETINS-OBSTETRICS: ACOG practice bulletin. Diagnosis and management of preeclampsia and eclampsia. Number 33, January 2002. Obstet Gynecol 99: 159-167, 2002.

AITKEN DA, MCCAW G, CROSSLEY JA, BERRY E, CONNOR JM, SPENCER K, MACRI JN: First trimester biochemical screening for fetal chromosome abnormalities and neural tube defects. Prenat Diagn 13: 681-689, 1993.

AUTIERO M, LUTTUN A, TJWA M, CARMELIET P: Placental growth factor and its receptor, vascular endothelial growth factor receptor-1: novel targets for stimulation of ischemic tissue revascularization and inhibition of angiogenic and inflammatory disorders. $J$ Thromb Haemost 1: 1356-1370, 2003.

BARTON JL, HERBST R, BOSISIO D, HIGGINS L, NICKLIN MJ: A tissue specific IL-1 receptor antagonist homolog from the IL-1 cluster lacks IL-1, IL-1ra, IL-18 and IL-18 antagonist activities. Eur J Immunol 30: 3299-3308, 2000.

BERNARD JP, CUCKLE HS, BERNARD MA, BROCHET C, SALOMON LJ, VILLE Y: Combined screening for open spina bifida at 11-13 weeks using fetal biparietal diameter and maternal serum markers. Am J Obstet Gynecol 209: 223.e1-5, 2013.

BREDAKI FE, POON LC, BIRDIR C, ESCALANTE D, NICOLAIDES KH: First trimester screening for neural tube defects using alpha-fetoprotein. Fetal Diagn Ther 31: 109-114, 2012.

BROCK DJ, SUTCLIFFE RG: Alpha-fetoprotein in the antenatal diagnosis of anencephaly and spina bifida. Lancet $\mathbf{2}$ : 197-199, 1972.

BUSFIELD SJ, COMRACK CA, YU G, CHICKERING TW, SMUTKO JS, ZHOU H, LEIBY KR, HOLMGREN LM, GEARING DP, PAN Y: Identification and gene organization of three novel members of the IL-1 family on human chromosome 2. Genomics 66: 213-216, 2000.

BUYON JP, CRONSTEIN BN, MORRIS M, TANNER M, WEISSMANN G: Serum complement values (C3 and C4) to differentiate between systemic lupus activity and pre-eclampsia. Am J Med 81: 194-200, 1986.

CANICK JA, KNIGHT GJ, PALOMAKI GE, HADDOW JE, CUCKLE HS, WALD NJ: Low second trimester maternal serum unconjugated oestriol in pregnancies with Down's syndrome. Br J Obstet Gynaecol 95: 330-333, 1988.

CHAOUAT G, LEDÉE-BATAILLE N, DUBANCHET S: Immune cells in uteroplacental tissues throughout pregnancy: a brief review. Reprod Biomed Online 14: 256-266, 2007.

COLE LA, KARDANA A, PARK SY, BRAUNSTEIN GD: The deactivation of hCG by nicking and dissociation. J Clin Endocrinol Metab 76: 704-710, 1993.

CUCKLE HS, WALD NJ, LINDENBAUM RH: Maternal serum alpha-fetoprotein measurement: a screening test for Down syndrome. Lancet 1: 926-929, 1984.

CURRY AE, VOGEL I, SKOGSTRAND K, DREWS C, SCHENDEL DE, FLANDERS WD, HOUGAARD DM, THORSEN P: Maternal plasma cytokines in early- and mid-gestation of normal human pregnancy and their association with maternal factors. J Reprod Immunol 77: 152-160, 2008.

DEBETS R, TIMANS JC, HOMEY B, ZURAWSKI S, SANA TR, LO S, WAGNER J, EDWARDS G, CLIFFORD T, MENON S, BAZAN JF, KASTELEIN RA: Two novel IL-1 family members, IL-1 delta and IL-1 epsilon, function as an antagonist and agonist of NF-kappa B activation through the orphan IL-1 receptor-related protein 2. J Immunol 167: 1440-1446, 2001.

DUCKITT K, HARRINGTON D: Risk factors for pre-eclampsia at antenatal booking: systematic review of controlled studies. BMJ 330: 565-571, 2005.

FERRER-OLIVERAS R, LLURBA E, CABERO-ROURA L, ALIJOTAS-REIG J: Prevalence and clinical usefulness of antiphospholipid and anticofactor antibodies in different Spanish preeclampsia subsets. Lupus 21: 257-263, 2012. 
FOSTER BP, BALASSA T, BENEN TD, DOMINOVIC M, ELMADJIAN GK, FLOROVA V, FRANSOLET MD, KESTLEROVA A, KMIECIK G, KOSTADINOVA IA, KYVELIDOU C, MEGGYES M, MINCHEVA MN, MORO L, PASTUSCHEK J, SPOLDI V, WANDERNOTH P, WEBER M, TOTH B, MARKERT UR: Extracellular vesicles in blood, milk and body fluids of the female and male urogenital tract and with special regard to reproduction. Crit Rev Clin Lab Sci 53: 379-395, 2016.

GIRARDI G, PROHÁSZKA Z, BULLA R, TEDESCO F, SCHERJON S: Complement activation in animal and human pregnancies as a model for immunological recognition. Mol Immunol 48: 1621-1630, 2011.

GONZÁLEZ-QUINTERO VH, SMARKUSKY LP, JIMÉNEZ JJ, MAURO LM, JY W, HORTSMAN LL, O'SULLIVAN MJ, AHN YS: Elevated plasma endothelial microparticles: preeclampsia versus gestational hypertension. Am J Obstet Gynecol 191: 1418-1424, 2004.

GULLER S, TANG Z, MA YY, DI SANTO S, SAGER R, SCHNEIDER H: Protein composition of microparticles shed from human placenta during placental perfusion: Potential role in angiogenesis and fibrinolysis in preeclampsia. Placenta 32: 63-69, 2011.

HOLDER BS, TOWER CL, JONES CJ, APLIN JD, ABRAHAMS VM: Heightened pro-inflammatory effect of preeclamptic placental microvesicles on peripheral blood immune cells in humans. Biol Reprod 86: 103, 2012.

HROMADNIKOVA I, KOTLABOVA K, ONDRACKOVA M, KESTLEROVA A, NOVOTNA V, HYMPANOVA L, DOUCHA J, KROFTA L: Circulating C19MC microRNAs in preeclampsia, gestational hypertension, and fetal growth restriction. Mediators Inflamm 2013: 186041, 2013.

HUPPERTZ B, FRANK HG, KINGDOM JC, REISTER F, KAUFMANN P: Villous cytotrophoblast regulation of the syncytial apoptotic cascade in the human placenta. Histochem Cell Biol 110: 495-508, 1998.

IDA A, TSUJI Y, MURANAKA J, KANAZAWA R, NAKATA Y, ADACHI S, OKAMURA H, KOYAMA K: IL-18 in pregnancy; the elevation of IL-18 in maternal peripheral blood during labour and complicated pregnancies. J Reprod Immunol 47: 65-74, 2000.

JIRECEK S, HOHLAGSCHWANDTNER M, TEMPFER C, KNÖFLER M, HUSSLEIN P, ZEISLER H: Serum levels of heat shock protein 70 in patients with preeclampsia: a pilot-study. Wien Klin Wochenschr 114: 730-732, 2002.

KALOUSOVÁ M, MURAVSKÁ A, ZIMA T: Pregnancy-associated plasma protein A (PAPP-A) and preeclampsia. Adv Clin Chem 63: 169-209, 2014.

KAMADA M, DAITOH T, HASEBE H, IRAHARA M, YAMANO S, MORI T: Blocking of human fertilization in vitro by sera with sperm-immobilizing antibodies. Am J Obstet Gynecol 153: 328-331, 1985.

KAMPINGA HH, HAGEMAN J, VOS MJ, KUBOTA H, TANGUAY RM, BRUFORD EA, CHEETHAM ME, CHEN B, HIGHTOWER LE: Guidelines for the nomenclature of human heat shock proteins. Cell Stress Chaperones 14: 105-111, 2009.

KARDANA A, COLE LA: The stability of hCG and free beta-subunit in serum samples. Prenat Diagn. 17(2): 141-147, 1997.

KESTLEROVÁ A, FEYEREISL J, FRISOVÁ V, MĚCHUROVÁ A, ŠŮLA K, ZIMA T, BĚLÁČEK J, MADAR J: Immunological and biochemical markers in preeclampsia. J Reprod Immunol 96: 90-94, 2012.

KIM TJ, KIM TH, LEE HJ, PEDDLE L, RAHMAN P, HU P, GREENWOOD CM, INMAN RD: Interleukin 1 polymorphisms in patients with ankylosing spondylitis in Korea. J Rheumatol 35: 1603-1608, 2008.

KNIGHT M, REDMAN CW, LINTON EA, SARGENT IL: Shedding of syncytiotrophoblast microvilli into the maternal circulation in pre-eclamptic pregnancies. Br J Obstet Gynaecol 105: 632-640, 1998.

KUMAR S, HANNING CR, BRIGHAM-BURKE MR, RIEMAN DJ, LEHR R, KHANDEKAR S, KIRKPATRICK RB, SCOTT GF, LEE JC, LYNCH FJ, GAO W, GAMBOTTO A, LOTZE MT: Interleukin-1F7B (IL-1H4/ IL-1F7) is processed by caspase-1 and mature IL-1F7B binds to the IL-18 receptor but does not induce IFN-gamma production. Cytokine 18: 61-71, 2002.

LEA WI, LEE YH: The associations between interleukin-1 polymorphisms and susceptibility to ankylosing spondylitis: A meta-analysis. Joint Bone Spine 79: 370-374, 2012.

LEAVEY K, BENTON SJ, GRYNSPAN D, KINGDOM JC, BAINBRIDGE SA, COX BJ: Unsupervised Placental Gene Expression Profiling Identifies Clinically Relevant Subclasses of Human Preeclampsia. Hypertension 68: 137-147, 2016. 
LÉDÉE-BATAILLE N, DUBANCHET S, COULOMB-L'HERMINE A, DURAND-GASSELIN I, FRYDMAN R, CHAOUAT G: A new role for natural killer cells, interleukin (IL)-12, and IL-18 in repeated implantation failure after in vitro fertilization. Fertil Steril 81: 59-65, 2004.

LÉDÉE-BATAILLE N, OLIVENNES F, KADOCH J, DUBANCHET S, FRYDMAN N, CHAOUAT G, FRYDMAN R: Detectable levels of interleukin-18 in uterine luminal secretions at oocyte retrieval predict failure of the embryo transfer. Hum Reprod 19: 1968-1973, 2004.

LEVINE RJ, HAUTH JC, CURET LB, SIBAI BM, CATALANO PM, MORRIS CD, DERSIMONIAN R, ESTERLITZ JR, RAYMOND EG, BILD DE, CLEMENS JD, CUTLER JA: Trial of calcium to prevent preeclampsia. $N$ Engl J Med 337: 69-76, 1997.

LIN TM, GALBERT SP, KIEFER D, SPELLACY WN, GALL S: Characterization of four human pregnancyassociated plasma proteins. Am J Obstet Gynecol 118: 223-236, 1974.

LO CICERO A, STAHL PD, RAPOSO G: Extracellular vesicles shuffling intercellular messages: for good or for bad. Curr Opin Cell Biol 35: 69-77, 2015.

LOK CA, JEBBINK J, NIEUWLAND R, FAAS MM, BOER K, STURK A, VAN DER POST JA: Leukocyte activation and circulating leukocyte-derived microparticles in preeclampsia. Am J Reprod Immunol 61: 346-359, 2009.

LUTTUN A, TJWA M, MOONS L, WU Y, ANGELILLO-SCHERRER A, LIAO F, NAGY JA, HOOPER A, PRILLER J, DE KLERCK B, COMPERNOLLE V, DACI E, BOHLEN P, DEWERCHIN M, HERBERT JM, FAVA R, MATTHYS P, CARMELIET G, COLLEN D, DVORAK HF, HICKLIN DJ, CARMELIET P: Revascularization of ischemic tissues by PlGF treatment, and inhibition of tumor angiogenesis, arthritis and atherosclerosis by anti-Flt1. Nat Med 8: 831-840, 2002.

MADÁCH K, MOLVAREC A, RIGÓ J JR, NAGY B, PÉNZES I, KARÁDI I, PROHÁSZKA Z: Elevated serum $70 \mathrm{kDa}$ heat shock protein level reflects tissue damage and disease severity in the syndrome of hemolysis, elevated liver enzymes, and low platelet count. Eur J Obstet Gynecol Reprod Biol 139: 133-138, 2008.

MARRAKCHI S, GUIGUE P, RENSHAW BR, PUEL A, PEI XY, FRAITAG S, ZRIBI J, BAL E, CLUZEAU C, CHRABIEH M, TOWNE JE, DOUANGPANYA J, PONS C, MANSOUR S, SERRE V, MAKNI H, MAHFOUDH N, FAKHFAKH F, BODEMER C, FEINGOLD J, HADJ-RABIA S, FAVRE M, GENIN E, SAHBATOU M, MUNNICH A, CASANOVA JL, SIMS JE, TURKI H, BACHELEZ H, SMAHI A: Interleukin-36-receptor antagonist deficiency and generalized pustular psoriasis. $N$ Engl J Med 365: 620-628, 2011.

MERKATZ IR, NITOWSKY HM, MACRI JN, JOHNSON WE: An association between low maternal serum alpha-fetoprotein and fetal chromosomal abnormalities. Am J Obstet Gynecol 148: 886-894, 1984.

MESSERLI M, MAY K, HANSSON SR, SCHNEIDER H, HOLZGREVE W, HAHN S, RUSTERHOLZ C: Feto-maternal interactions in pregnancies: placental microparticles activate peripheral blood monocytes. Placenta 31: 106-112, 2010.

MEZIANI F, TESSE A, DAVID E, MARTINEZ MC, WANGESTEEN R, SCHNEIDER F, ANDRIANTSITOHAINA R: Shed membrane particles from preeclamptic women generate vascular wall inflammation and blunt vascular contractility. Am J Pathol 169: 1473-1483, 2006.

MINCHEVA-NILSSON L, BARANOV V: The role of placental exosomes in reproduction. Am J Reprod Immunol 63: 520-533, 2010.

MOLVAREC A, PROHÁSZKA Z, NAGY B, SZALAY J, FÜST G, KARÁDI I, RIGÓ J JR: Association of elevated serum heat-shock protein 70 concentration with transient hypertension of pregnancy, preeclampsia and superimposed preeclampsia: a case-control study. J Hum Hypertens 20: 780-786, 2006.

MOLVAREC A, PROHÁSZKA Z, NAGY B, KALABAY L, SZALAY J, FÜST G, KARÁDI I, RIGÓ J JR: Association of increased serum heat shock protein 70 and C-reactive protein concentrations and decreased serum alpha(2)-HS glycoprotein concentration with the syndrome of hemolysis, elevated liver enzymes, and low platelet count. $J$ Reprod Immunol 73: 172-179, 2007.

MOLVAREC A, RIGÓ J JR, LÁZÁR L, BALOGH K, MAKÓ V, CERVENAK L, MÉZES M, PROHÁSZKA Z: Increased serum heat-shock protein 70 levels reflect systemic inflammation, oxidative stress and hepatocellular injury in preeclampsia. Cell Stress Chaperones 14: 151-159, 2009. 
MORIMOTO RI, TISSIERES A, GEORGOPOULOUS C: The Stress Response, Function of the Proteins and Perspective. Stress Proteins in Biology and Medicine. R.I. Morimoto, A. Tissieres, C Georgopoulous (eds.). New York: Cold Spring Harbor Press, 1990, pp. 1-36.

MULERO JJ, PACE AM, NELKEN ST, LOEB DB, CORREA TR, DRMANAC R, FORD JE: IL1HY1: A novel interleukin-1 receptor antagonist gene. Biochem Biophys Res Commun 263: 702-706, 1999.

MURRIETA-COXCA JM, RODRÍGUEZ-MARTÍNEZ S, CANCINO-DIAZ ME, MARKERT UR, FAVARO RR, MORALES-PRIETO DM: IL-36 Cytokines: regulators of inflammatory responses and their emerging role in immunology of reproduction. Int J Mol Sci 20: pii: E1649, 2019.

NOVER L: Heat Shock Response of Eukaryotic Cells. L. Nover (ed.) Springer Vet-lag; Berlin, Heidelberg, New York, Tokyo, 1984.

ONOUFRIADIS A, SIMPSON MA, PINK AE, Di MEGLIO P, SMITH CH, PULLABHATLA V, KNIGHT J, SPAIN SL, NESTLE FO, BURDEN AD, CAPON F, TREMBATH RC, BARKER JN: Mutations in IL36RN/IL1F5 are associated with the severe episodic inflammatory skin disease known as generalized pustular psoriasis. $A m$ J Hum Genet 89: 432-437, 2011.

ORR B, GODEK KM, COMPTON D: Aneuploidy. Curr Biol 25: R538-R542, 2015.

PERAÇOLI JC, BANNWART-CASTRO CF, ROMAO M, WEEL IC, RIBEIRO VR, BORGES VT, RUDGE MV, WITKIN SS, PERAÇOLI MT: High levels of heat shock protein 70 are associated with pro-inflammatory cytokines and may differentiate early- from late-onset preeclampsia. J Reprod Immunol 100: 129-134, 2013.

REDMAN CW, SARGENT IL: Circulating microparticles in normal pregnancy and pre-eclampsia. Placenta 29 (Suppl A): S73-77, 2008.

REDMAN CW, SARGENT IL: Latest advances in understanding preeclampsia. Science 308: 1592-1594, 2005.

REDMAN CW, TANNETTA DS, DRAGOVIC RA, GARDINER C, SOUTHCOMBE JH, COLLETT GP, SARGENT IL: Review: Does size matter? Placental debris and the pathophysiology of pre-eclampsia. Placenta 33 (Suppl): S48-54, 2012.

ROOS MA, GENNERO L, DENYSENKO T, REGUZZI S, CAVALLO G, PESCARMONA GP, PONZETTO A: Microparticles in physiological and in pathological conditions. Cell Biochem Funct 28: 539-548, 2010.

SEBIRE NJ, SPENCER K, NOBLE PL, HUGHES K, NICOLAIDES KH: Maternal serum alpha-fetoprotein in fetal neural tube and abdominal wall defects at 10 to 14 weeks of gestation. Br J Obstet Gynaecol 104: 849-851, 1997.

SIBAI B, DEKKER G, KUPFERMINC M: Pre-eclampsia. Lancet 365: 785-799, 2005.

SITAR S, KEJŽAR A, PAHOVNIK D, KOGEJ K, TUŠEK-ŽNIDARIČ M, LENASSI M, ŽAGAR E: Size Characterization and Quantification of Exosomes by Asymmetrical - Flow Field - Flow Fractionation. Anal Chem 87: 9225-9233, 2015.

SMITH DE, RENSHAW BR, KETCHEM RR, KUBIN M, GARKA KE, SIMS JE: Four new members expand the interleukin-1 superfamily. J Biol Chem 275: 1169-1175, 2000.

SOUTHCOMBE JH, REDMAN CW, SARGENT IL, GRANNE I: Interleukin-1 family cytokines and their regulatory proteins in normal pregnancy and pre-eclampsia. Clin Exp Immunol 181: 480-490, 2015.

SPENCER K, KHALIL A, BROWN L, MILLS I, HORNE H: First trimester maternal serum alpha-fetoprotein is not raised in pregnancies with open spina bifida. Prenat Diagn 34: 168-171, 2014.

SPRINGER D, ZIMA T, ARNOSTOVÁ L: Stability of free beta-hCG in the routine screening of Down syndrome in the first trimester of pregnancy. Prague Med Rep 109: 134-141, 2008.

TAN MY, SYNGELAKI A, POON LC, ROLNIK DL, O'GORMAN N, DELGADO JL, AKOLEKAR R, KONSTANTINIDOU L, TSAVDARIDOU M, GALEVA S, AJDACKA U, MOLINA FS, PERSICO N, JANI JC, PlaSENCIA W, GRECO E, PAPAIOANNOU G, WRIGHT A, WRIGHT D, NICOLAIDES KH: Screening for Pre-eclampsia by Maternal Factors and Biomarkers at 11-13 weeks' Gestation. Ultrasound Obstet Gynecol 52: 186-195, 2018.

TAYLOR BD, TANG G, NESS RB, OLSEN J, HOUGAARD DM, SKOGSTRAND K, ROBERTS JM, HAGGERTY CL: Mid-pregnancy circulating immune biomarkers in women with preeclampsia and normotensive controls. Pregnancy Hypertens 6: 72-78, 2016. 
TAYLOR BD, NESS RB, KLEBANOFF MA, ZOH R, BASS D, HOUGAARD DM, SKOGSTRAND K, HAGGERTY CL: First and second trimester immune biomarkers in preeclamptic and normotensive women. Pregnancy Hypertens 6: 388-393, 2016.

TESSE A, MEZIANI F, DAVID E, CARUSIO N, KREMER H, SCHNEIDER F, ANDRIANTSITOHAINA R: Microparticles from preeclamptic women induce vascular hyporeactivity in vessels from pregnant mice through an overproduction of NO. Am J Physiol Heart Circ Physiol 293: H520-525, 2007.

TOKMADZIĆ VS, TSUJI Y, BOGOVIĆ T, LASKARIN G, CUPURDIJA K, STRBO N, KOYAMA K, OKAMURA H, PODACK ER, RUKAVINA D: IL-18 is present at the maternal-fetal interface and enhances cytotoxic activity of decidual lymphocytes. Am J Reprod Immunol 48: 191-200, 2002.

TOWNE JE, RENSHAW BR, DOUANGPANYA J, LIPSKY BP, SHEN M, GABEL CA, SIMS JE: Interleukin-36 (IL-36) ligands require processing for full agonist (IL-36alpha, IL-36beta, and IL-36gamma) or antagonist (IL-36Ra) activity. J Biol Chem 286: 42594-42602, 2011.

ULCOVA-GALLOVA Z: The role of antiphospholipid antibodies (aPls) in infertile women: the long-lasting experience. Reprod Med Biol 14: 49-55, 2014.

VANWIJK MJ, NIEUWLAND R, BOER K, VAN DER POST JA, VANBAVEL E, STURK A: Microparticle subpopulations are increased in preeclampsia: possible involvement in vascular dysfunction? Am $\mathrm{J}$ Obstet Gynecol 187: 450-456, 2002.

VARGA Z, YUANA Y, GROOTEMAAT AE, VAN DER POL E, GOLLWITZER C, KRUMREY M, NIEUWLAND R: Towards traceable size determination of extracellular vesicles. J Extracell Vesicles 4: 3, 2014.

WANGEL AG, KONTIAINEN S, SCHEININ T, SCHLENZKA A, WANGEL D, MÄENPÄÄ J: Anti-endothelial cell antibodies in insulin-dependent diabetes mellitus. Clin Exp Immunol. 88: 410-413, 1992.

WAGNER LK: Diagnosis and management of preeclampsia. Am Fam Physician 70: 2317-2324, 2004.

WALD NJ, CUCKLE HS, DENSEM JW, NANCHAHAL K, ROYSTON P, CHARD T, HADDOW JE, KNIGHT GJ, PALOMAKI GE, CANICK JA: Maternal serum screening for Down's syndrome in early pregnancy. $B M J 297$ : 883-887, 1988.

WALD NJ, KENNARD A, DENSEM JW, CUCKLE HS, CHARD T, BUTLER L: Antenatal maternal serum screening for Down's syndrome: results of a demonstration project. BMJ 305: 391-394, 1992.

ZAKIYANOV O, KRIHA V, VACHEK J, ZIMA T, TESAR V, KALOUSOVA M: Placental growth factor, pregnancyassociated plasma protein-A, soluble receptor for advanced glycation end products, extracellular newly identified receptor for receptor for advanced glycation end products binding protein and high mobility group box 1 levels in patients with acute kidney injury: a cross sectional study. BMC Nephrol 14: 245, 2013.

ZHENG YW, CHAN KC, SUN H, JIANG P, SU X, CHEN EZ, LUN FM, HUNG EC, LEE V, WONG J, LAI PB, LI CK, CHIU RW, LO YM: Nonhematopoietically derived DNA is shorter than hematopoietically derived DNA in plasma: a transplantation model. Clin Chem 58: 549-558, 2012. 